\title{
Indigenous water management
}

The idea for this special issue crystallised at the annual river conference, 'Riversymposium', in Brisbane in 2017. Riversymposium has for a number of years provided a supportive platform for the First Peoples of Australia (and elsewhere) to profile their efforts, achievements, knowledge, ideas, and aspirations in the water arena. By 2017 there was sufficient interest in the topic of Indigenous water management to justify an entire parallel session at the conference, and related topics under the banner of 'Indigenous or First nation's water issues', 'cultural flows' and 'Indigenous water knowledge' have since become standing themes in its annual program.

This special issue brings together some of those who contributed to that rich session and others at the conference. It also marks other milestones in Australia's water story. It is now fifteen years since policy-makers first recognised Indigenous rights and interests in national water policy and added the issue to the many others that had preoccupied water reformers during the previous decade, albeit giving it limited treatment (Jackson and Morrison 2007). While many have rightly noted this late recognition as a glaring omission, coming more than a decade after the Mabo High Court decision and the Native Title Act (Cth) (see Taylor et al. 2017; Hartwig et al. 2018; Jackson 2015; Marshall 2017; O’Bryan 2019), it has nonetheless provided an impetus for change in how we manage water, and the ways in which we seek knowledge of water, as well as appreciate its critical importance to all groups in Australian society. An important illustration of the degree to which water management agencies recognise the need for Indigenous voices can be found in the recent decision of the Ministerial Council for the Murray Darling Basin (MDB) to add an Indigenous member to the MDB Authority.

It is also just over a decade since leaders of the Aboriginal nations of the Murray and lower Darling Rivers, represented by MLDRIN (Murray Lower Darling Rivers Indigenous Nations), articulated their aspirations for cultural flows in the Echuca Declaration (MLDRIN 2009). The Declaration affirmed the sovereignty of nations, defined cultural flows and outlined a strategy for enhancing Aboriginal rights and interests in water allocation planning. The cultural flows strategy has sought to leverage water allocations off the success of the environmental flow concept, but in a manner that stakes out a distinct and vital role for Aboriginal nations in water management. A year after the $10^{\text {th }}$ anniversary of the Echuca Declaration (MDLRIN 2009), Aboriginal organisations released the results of a research program intended to embed water allocations within Australia's water management systems (Mooney and Cullen 2019). The National Cultural Flows Research Project explores new institutional configurations and Indigenous-led methodologies to define and apply cultural flows, to determine the flow regimes required at case study sites, and to measure the socio-cultural, economic, and health benefits that may ensue (MLDRIN et al. 2017). In response, governments have committed to supporting implementation with funds for MLDRIN and NBAN, as Mooney and Cullen explain in their article on an allied research methodology, the Aboriginal Waterway Assessment (2019).

Support from the MDBA has been essential to the success of both confederations that represent Aboriginal nations of the southern and northern basin (MLDRIN and the Northern Basins 
Aboriginal Nations (NBAN)). Three articles in this collection speak directly to the issue of nation-building, institutional capacity and self-determination in water governance (Hemming et al. 2019; Poelina et al. 2019; and Mooney and Cullen, 2019). In the article by Hemming et al. (2019), the authors make the important and often overlooked point that Aboriginal nations have distinctly political goals when they engage in water policy development and protection or restoration of country.

A sound evidence base and strong representation have also proved important to progressing Indigenous water management beyond the crisis-afflicted MDB. A decade ago, the National Water Commission (NWC) funded research to support the North Australian Indigenous Land and Sea Management Alliance's Indigenous Water Policy Group to develop water policy for Aboriginal Land Councils across the tropical north and respond to the push for northern water resource development that has been promoted largely in their absence (Jackson and Altman 2009). The NWC established the first Indigenous water advisory group - the First Peoples Water Engagement Council. It also worked collaboratively to lift the standards of water planning and improve the chances of meeting the expectations of the NWI when it held two national meetings on Indigenous water planning with traditional owner groups and water planners in 2009 and 2011.

Based on these early moves, the state governments of NSW, South Australia and Victoria started to invest their own resources into building Aboriginal water management expertise in their agencies and in developing partnerships with First Nations. Some now fund catchment management agencies, native title groups, or Land Councils, to engage in water planning processes and environmental water management activities. Others, such as Queensland and Western Australia, are also taking steps in this direction in recognition of the critical importance of rivers like the Fitzroy (Martuwarra) in the Kimberley to traditional owners and national heritage (Poelina et al. 2019). The emergence of the Martuwarra (Fitzroy River) Council holds much promise for collaborative water governance in a region held predominantly under native title. The article by Anne Poelina (who is the Chairperson of the Council) and others (2019) leads with an abstract in Anne's Nygina language, a precedent that we hope many other Australian journals will follow.

Water planning is not the only water management arena to see change. Through the Snowy scheme's operational management process, water and energy managers have started to include traditional owners in decision-making. The article by Williams et al. (2019) describes the steps taken to address some of the needs of the five communities that have a direct connection to the waterways of the Snowy Mountains and an interest in the operations of the hydroelectric scheme. The article shows how agencies have engaged with traditional owners to shape and name specific flows (releases from the dam) after significant features of the Aboriginal world.

There have however been set backs to the Aboriginal water movement, as revealed by the article by Moggridge et al. (2019) on developments in NSW. Moggridge et al. (2019) highlight the effects of policy change and inconsistent funding on the efforts of Aboriginal people to contribute to an extremely complex policy area and to try to do so on their own terms. The 
demise of the Aboriginal Water Unit from NSW's water sector represents a lost opportunity that is similar to that experienced when the Abbott Government abolished the First People's Water Engagement Council (2010-14), leaving the field with no national forum for representing Aboriginal peoples' positions, perspectives or policies to government. Control over data is a focal theme for the article Brad Moggridge led, as it is for the article by Mooney and Cullen (2018) on the Aboriginal Waterway Assessment, which has rolled out rapidly in the southern Murray-Darling basin over recent years.

Despite the strides forward in consultation and engagement, Aboriginal nations remain greatly constrained in their ability to shape the use and management of water. Rates of water holding or ownership of entitlements are woefully skewed against Aboriginal people, a disparity that contrasts with the degree to which Indigenous Australians can make decisions about the use and management of land (Jackson 2017). Unfortunately, the NWC's evaluation of national progress in this area formulated five years ago still holds true:

Most jurisdictions have ... generally failed to incorporate effective strategies for achieving Indigenous objectives in water planning arrangements. While recognition of Indigenous cultural values and associated water requirements has progressed, implementation of practical change remains variable, with most jurisdictions as yet not making specific provision for water access for Indigenous people (NWC 2014, p.31).

As researchers closely involved in this area for over a decade we are well aware of the obstacles and constraints, but we also see progressive and positive developments in many places and most of all on the ground in communities. The years of advocating for greater opportunities for involvement under the auspices of national water policy have seen the generation of much local activity, as the articles in this collection show. Across the country, and especially in the Murray Darling Basin states, there is a flourishing of community-based Indigenous water management projects. The efforts described in these articles to articulate Aboriginal management and governance objectives, values and principles, to reform government-led approaches, to negotiate with states over water rights, and partner with NGOs to direct and use environmental water (Jackson and Nias 2019), show the diversity of ways in which Aboriginal people are today managing water.

Although so far largely travelling in parallel with the well-established Indigenous NRM or caring for country sector (Altman and Kerins 2012), the work profiled here is making a significant contribution to Australia's environmental management efforts. There is no doubt that this relatively new field would benefit from more attention from policy makers, funders, researchers, NGOs, and the wider public. It could also benefit from reflection by those communities, researchers, policy-makers and practitioners who have built it up over the past fifteen to twenty years, and those who are keen to learn more about what others are doing, what has worked, what has not, as well as what next steps will need to be taken to advance Aboriginal peoples' rights and interests in water. 
Jackson, S. and B. Moggridge 2019. Editorial published in the Australasian Journal of Environmental Management vol. 26.

This is why we are very pleased to bring together this set of articles that profile the work being undertaken in this field and to reflect on progress, successes, barriers, outstanding challenges and prospects for the future. We hope that by bringing this work together in one issue of this journal we can celebrate community achievements, mark the significance of this rapidly evolving field, and potentially catalyse further advances in policy, research and practice.

\section{Funding and acknowledgements}

This project was supported by the Australian Research Council's Future Fellowships Program funding scheme (project number FT130101145). We would like to acknowledge Helen Ross and the journal's editorial team for backing this special issue and for their assistance in bringing the articles to publication.

\section{References}

Altman, J. and S. Kerins (Eds) 2012. People on Country: Vital Landscapes, Indigenous Futures. Sydney: Federation Press.

Hartwig, L., Jackson, S. and N. Osborne 2018. Recognition of Barkandji water rights in Australian settler-colonial water regimes. Resources 7(1): 16; doi:10.3390/resources7010016

Hemming, S. Rigney, D., Bignall, S., Berg, S. and G. Rigney 2019. "Indigenous Nation Building for Environmental Futures: Murrundi (River Murray) Flows through Ngarrindjeri Country." Australasian Journal of Environmental Management

Jackson, S. and J. Morrison. 2007. "Indigenous Perspectives on Water Management, Reforms and Implementation." In Managing Water for Australia: The Social and Institutional Challenges, edited by K. Hussey and S. Dovers, 23-41. Melbourne: CSIRO.

Jackson, S. 2017. "Enduring Injustices in Australian Water Governance." In Natural Resources and Environmental Justice: The Australian Experience, edited by A. Lukasiewicz, Dovers, S., Robin, L., McKay, J., Schilizzi, S and S. Graham, 121-132. Melbourne: CSIRO.

Jackson, S. and J. Altman. 2009. "Indigenous rights and water policy: perspectives from tropical northern Australia." Australian Indigenous Law Review 13(1): 27-48.

Jackson, S. and D. Nias. 2019. "Watering Country: Aboriginal partnerships with environmental water managers of the Murray-Darling Basin, Australia." Australasian Journal of Environmental Management

Marshall, V. 2017. Overturning Aqua Nullius. Canberra: Aboriginal Studies Press.

Moggridge, B., Betteridge, L. and R. Thompson. 2019. "Integrating Aboriginal cultural values into water planning: a case study from New South Wales, Australia." Australasian Journal of Environmental Management 
Jackson, S. and B. Moggridge 2019. Editorial published in the Australasian Journal of Environmental Management vol. 26.

Mooney, W. and A. Cullen. 2019. "Implementing the Aboriginal Waterways Assessment tool: collaborations to engage and empower First Nations in waterway management." Australasian Journal of Environmental Management

MLDRIN 2009. The Echuca Declaration https://www.mdba.gov.au/sites/default/files/pubs/samldrin-echuca-declaration-2009.PDF

National Water Commission 2014 National Water Commission, 2014. Fourth Assessment of the National Water Initiative, Canberra.

O’Bryan. K. 2019. Indigenous Rights and Water Resource Management: Not Just Another Stakeholder. Abingdon: Routledge.

Poelina, A., Taylor, K and I. Prendergast. 2019. "Martuwarra Fitzroy River Council: a cultural approach to collaborative water governance in an Aboriginal and National Heritage listed area." Australasian Journal of Environmental Management.

Taylor, K., B. Moggridge, and A. Poelina. 2017. "Australian Indigenous Water Policy and the Impacts of the Ever-changing Political Cycle." Australasian Journal of Water Resources 20: $132-147$.

Weir, J. 2009. Murray River Country: An Ecological Dialogue with Traditional Owners. Canberra: Aboriginal Studies Press.

Williams, S., Connolly, D. and A. Williams 2019. "The recognition of cultural water requirements in the montane rivers of the Snowy Mountains, Australia." Australasian Journal of Environmental Management

MLDRIN, NBAN and NAILSMA 2017 National Cultural Flows Research Project, http://culturalflows.com.au/

Sue Jackson

Australian Rivers Institute

Griffith University

Nathan QLD 4222

Sue.jackson@griffith.edu.au

ORCID: 0000-0001-6498-5783

Brad Moggridge

University of Canberra 